\title{
(Re)thinking Postsocialism: Interview with Neda Atanasoski and Kalindi Vora
}

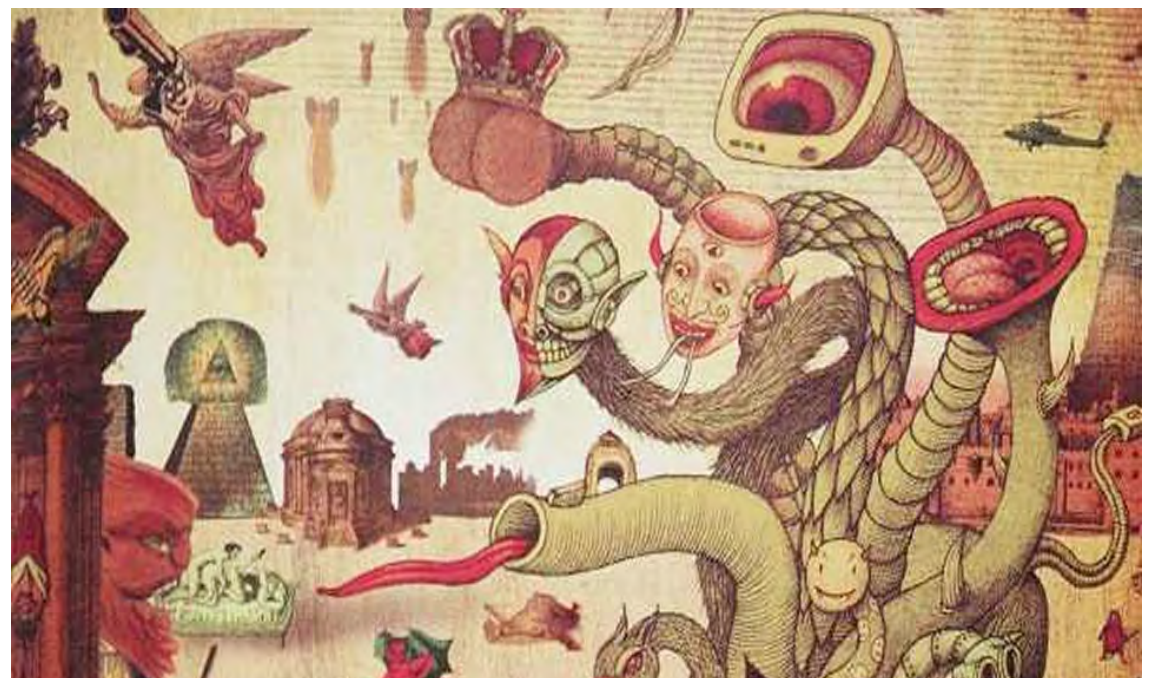

The dominance of present-day liberal politics, which collapse political notions of freedom with the unrestricted spread of free markets, and justice with liberal rights-based outcomes, beg for an extended exploration of the aftermaths of the social, politi$\mathrm{cal}$, and cultural disappearance and subsequent reconfiguration of a socialist political imaginary.

Atanasoski and Vora 2018, 152

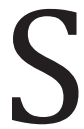
ince 1950-60s, decolonial and postcolonial scholars have studied mechanisms of global coloniality that have produced racial, gender, and economic order of global systems and that have defined the human and who is eligible to humanity. Sylvia Wynter (2003) states that the struggle of our times is the struggle against the overrepresentation of the Western conception of Man that pretends to be the human itself. The concept of the human incorporates a certain descriptive statement of eligibility and ineligibility, according to which the hegemonic Western construction of Man/ Human

Photo: "La Hidra Capitalista” by Mauricio Gómez Morín

(C) Lesia Pagulich, Tatsiana Shchurko 2020

(C) Feminist Critique: East European Journal of Feminist and Queer Studies 2020, № 3, p. 91-111;

http://feminist.krytyka.com (ISSN 2524-2733) 
depends on the Other who is produced as barbarian, not capable of reason, therefore, sub-rational, sub-human/non-human. Thus, Wynter describes a foundational mechanism of global coloniality that has produced racialization and colonization as a global system. She maintains that "one cannot 'unsettle' the 'coloniality of power' without a redescription of the human outside the terms of our present descriptive statement of the human, Man, and its overrepresentation" (Wynter 2003, 268). In turn, Aníbal Quijano (2000) argues that colonization of Americas produced a new hegemonic global order, global coloniality of power, according to which "race became the fundamental criterion for the distribution of the world population into ranks, places, and roles in the new society's structure of power" (p. 535). Quijano adds that the global coloniality of power determined a new global model of labor control, capitalism (Quijano 2000, 535-536). Thus, decolonial theory, critical race theory, Black feminist thought and queer of color critique have powerful tools and theoretical frameworks to address such issues as colonialism, imperialism, and structural inequality in the transnational perspective. For example, Denise Ferreira da Silva (2014) states that decolonization is "the unknowing and undoing of the World that reaches its core" (da Silva 2014, 85); it consequently "requires that knowing and doing be emancipated from Thought, unhinged from the many ways in which Thought - the said seat of the universal - is limited, constrained, and arrested by Truth" (da Silva 2014, 86). In other words, in order to produce other narratives and ways of knowing and understanding the world, one has to go beyond the scripts of modernity. As Boaventura de Sousa Santos argues, the "task" for a radical thinker is "to imagine new ways of theorizing and of generating transformative collective action" (de Sousa Santos 2014, 5).

What is the place of postsocialist studies in these conversations about global coloniality of power? The term "postsocialism" is often used solely in relation to the specific former state socialist spaces and is rarely included in the scholarly discussions about colonialism and imperialism. This approach narrows the possibilities of other interpretations and analytic potential of postsocialism. Also, the predominance of "racelessness" and the idea of the inapplicability of "race" to the former state socialist region reinforces hierarchical scripts that lead to the exclusion of non-Slavic people and perpetuates racialization in the regions.

Moreover, the liberal rhetoric of human rights and multiculturalism often dominates the discussions of political action and resistance to the power structures, discursively cementing liberalism as the only possible choice in the struggle for social justice, while liberal formations themselves are rooted in colonialism and slavery (Atanasoski 2013, Hartman 1997, Douzinas 2007, Lowe 2015, Manokha 2009). The logic of Western liberal "progress" and liberal capitalist model are presented as the only options for the former state socialist countries against the Soviet "backwardness."

Therefore, the following question emerges: what does it mean to practice 
radical thinking that opens up possibilities for radical imaginations outside the scripts of modernity and predetermined "solutions" of capitalism? We are searching for forms of thinking that allow a disruptive potential of knowledge production, including the disruption of the totalizing logic of neoliberalism as the undisputed universal Good. We must hold on to the option to say "No" to the "easily acceptable liberal face" offered on the dominant's terms (Trinh 2016). The refusal to be legible, rational, and liberally recognized keeps the door open for reimagining.

One such example of radical thinking that counteracts the standardized, simplified and one-dimensional interpretation of postsocialism, as well as looks for "an emerging political imaginary that connects already existing localized economic alternatives to capitalism" (Atanasoski and Vora 2018, 140 ) is the special issue Postsocialist Politics and the Ends of Revolution of the journal Social Identities (online publication May 2017; print publication Winter 2018). The following interview is a conversation with the editors of this special issue: Neda Atanasoski and Kalindi Vora. In the "Introduction" to the issue, Neda Atanasoski and Kalindi Vora pose questions that explore: What does it mean to demand thinking of postsocialism or "postsocialist reading practices" that do not use the tropes legitimized by Western reason? How to center postsocialist imaginaries, "radical and decolonial imaginaries of collectivity and political action" (Atanasoski and Vora 2018, 142) that destabilize and dismantle Western hegemony, imperialism, colonialism, and racial capitalism? Can postsocialism simultaneously be a critique of coloniality of knowledge, of imperial and colonial difference, and a theory of political action, ethical solidarity, and coalitions? They push the bounds and definition of postsocialism by freeing it from a homogenized history tied to state socialism and European thought of traditional Marxian teleologies (Atanasoski and Vora 2018, 140) in order to explore "how socialist legacies at multiple scales, expanding beyond state socialism and the Communist International, have (or have not) remained constitutive of contemporary radical and decolonial imaginaries of collectivity and political action" (Atanasoski and Vora 2018, 142). Atanasoski and Vora make a powerful intervention into conceptualizations of postsocialism, focusing on the legacies of a plurality of socialisms and postsocialism as a global condition and a temporal analytic that questions the very forms of established thinking and paradigms of epistemological genealogies (Atanasoski and Vora 2018, 143, 151). In this sense, Atanasoski and Vora offer a complex and nuanced engagement with time and space in relation to postsocialisms. They suggest looking at obscured historical connections between past and present examples of political solidarity and coalitions that expand approaches to politics and futurity.

Using this special issue as a collaborative platform, in our conversation with Neda Atanasoski and Kalindi Vora, we would like to contemplate on radical possibilities of postsocialisms and the potential of postsocialist reading practices to situate the former state socialist regions, such as Balkans and Eastern Europe, in the conversations about global coloniality. 


\section{Postsocialisms}

We [Lesia Pagulich and Tatsiana Shchurko] would like to start with the question of how the idea of this special issue Postsocialist Politics and the Ends of Revolution came about? Why is this special issue important? Why do you think it is important to reimagine postsocialisms?

We [Neda Atanasoski and Kalindi Vora] became friends and collaborators through discussions of the political, economic, and historical conditions in India and the former Yugoslavia that ran in provocatively parallel tracks. How could we explain the similarities in the ways that people in the subcontinent and in Eastern Europe looked after each other informally through a sense of commitment to greater society? Why were there connected commodity circuits and labor markets forming in these two regions, connected at times by grey economies and informal trade circuits? And this in the face of such different political histories? We realized that the socialist legacies of each region connected them, as well as to other global sites. Postcolonial studies offered tools for understanding Soviet imperialism, yet came from regions with very different racialized, gendered, and sexualized dynamics of power that accompanied the European colonial form of economic domination. At the same time, postsocialist studies was actively excavating and engaging the impact of socialism on cultural and political life in Eastern Europe in a way that did not seem to gain traction as a way to understand the socialist commitments of newly independent governments in the third world who were non-aligned but initiated social welfare and redistribution policies to protect newly launched national economies, policies that continue in some places until the present.

In the US and northern Europe, since the 1980s, we have been seeing a shift away from social welfare and distribution policies across continents and towards privatization and individualization of social interactions. With this movement away from "society" as a whole, and with no unified global political economic imaginary to stand as a counterexample to capitalism, the political left in the US has stumbled. As we mention in the "Introduction," there has been a sort of melancholic relationship to socialist imaginaries as something lost. We realized the folly of this state of despair together, given our experience living and working in parts of the world where socialist imaginaries still live active lives and shape policy and politics. In 2010 we organized a research group to think about these political and economic patterns, as well as imaginaries, arising from socialism under the theme of postcolonial contexts and postsocialist legacies. This grew into a 10 week residential research group at the University of California Humanities Research Institute where we assembled a group of scholars thinking through the relationship between imperialism, socialism, and capitalism in different world regions. Thinking together with that group inspired us to form this anthologie, and several participants from that group are contributors to the special issue of Social Identities. 
Importantly, in addition to thinking through the relationship between imperialism, socialism, and capitalism, your conceptualization of postsocialism is also in dialogue with queer theory. As you state, postsocialism "marks a queer temporality" (Atanasoski and Vora 2018, 141) which is crucial to question the politics of time-space and the writing of history. And, if we understand your ideas correctly, in the case of postsocialism, it means that postsocialism, being detached from specific geography, unveils the cultural and material violence by calling into question dominant historical narratives as well as searches for other relations with historical pasts and unexpected collaborations that resist normative concepts of time and history as linear, teleological, and progress-oriented. In this sense, how do you conceptualize queer temporality in relation to postsocialism? Why is "queer" important for you in this conceptualization?

Part of the legacy of socialist imaginaries, particularly in the formerly non-aligned or "third world" nations, is the notion that coloniality and capitalism did not successfully write over the lifeworlds that preceded it and continued despite it. This is a different argument from a Marxist teleology, where capitalism will generate the conditions of its own eventual demise. Perhaps capitalism may yet produce the conditions of its own destruction, but the subaltern, decolonial and postcolonial thinkers we cite, as well as those you cite, have asserted that capitalism was never a singular socio-cultural political and economic system that simply reproduces itself in whole cloth. It is an argument that capitalism produces a sense of linearity and indeed produces its own futurity, but to concede that this is "time" and "history" itself is to ignore all of these lifeworlds and thinkers who have struggled to show all of the worlds that co-exist in ways that sometimes coincide, and sometimes do not coincide, with a world that claims to be a unified (capitalist) whole, reproducing itself through institutions both economic and cultural. One of the qualities we ascribe to postsocialisms, though not exclusive to postsocialisms, is cross-filiations between groups that are not organized by descent from a singular socialist past, but that belongs to political and ethical histories that are compatible while each still belongs to its own "time." These are histories that are still unfolding towards unknown conclusions. The queerness of postsocialisms, in our sense, is that they are propelled by political desires that do not aim to reproduce capitalist reality, nor are these groups that are somehow unified in their political desires just because they bear socialist legacies. We may not even yet know what these radical political desires move toward. This is part of their queerness. To simply capitulate to a left melancholy that laments the failure of socialist ethics, as we note in the article, is to recognize only the capitalist lifeworld and only its own reproductive drive and temporality.

Another aspect of postsocialism that we find to be queer is the way in which this term can signal those lifeworlds that are not aligned (or brush 
against the grain) with a temporality of Europeanization or neoliberal development. The concept signals those political-economic-social projects that run against liberal temporality that ends in "democracy" "individual rights" or "juridical transparency." We can think about how certain imperial projects are even seen as not leading to the development of this modern world (the Russian, the Ottoman) as opposed to say the British or French empires that are viewed as central to the making of this modern world. So socialism is one such "aberrant" project that is seen as needing to be erased (bringing Central and Eastern Europe back into the fold of proper European development).

In response to your answer, thinking about projects that run against liberal temporality reminds us of one more dimension of queer temporality, that is the interconnectedness of the concept "queer" with questions of coloniality of gender and sexuality, institutionalized unmarked whiteness, heterosexuality, and gender normativity. For example, Jaclyn I. Pryor (2017) in her recent book Time Slips. Queer Temporalities, Contemporary Performance, and the Hole of History introduces the concept of "time slips," which she defines as moments of experiencing time queerly. Specifically, "time slips" refers to a shift from linear, teleological, capitalist, "straight time" to "queer time/ temporality" that defies "the logic of capitalist accumulation, as well as the presumed naturalness of a sense of time that is governed by an imperative to own property, produce offspring, establish stability, accumulate wealth, and ensure inheritance" (Pryor 2017, 4). Pryor conceptualizes "straight time" as linear teleological time, produced by the logic of capitalism, heteronormativity, racism, and colonial politics. In other words, "straight time" produces individual and collective experiences of trauma for those bodies, which are out of sync, marginalized queer and trans people, people of color, and other subaltern subjects, and forecloses processes of reparation and accountability. So, it is interesting to think how postsocialisms defy "straight time," embracing the lifeworlds of non-normative bodies and "out of sync" collectivities. Pryor's ideas also speak to your understanding of postsocialism as detached from certain tempo-locality and focused on centering non-european non-white experiences of socialism that are "out of sync" with Western time, space and epistemology. Consequently, we would like to move to the question about geographies, spaces and localities. In the "Introduction" to the special issue Postsocialist Politics and the Ends of Revolution, you state that you want to free postsocialism from the particular geographical location in order to articulate postsocialism as a global condition, "not one that just affects the former Soviet-bloc" (Atanasoski and Vora 2018, 143). At the same time, you envision the postsocialist conditions as both global and "contradictory localized." Could you elaborate on the relation between postsocialism and locality? 
We were interested in thinking about postsocialism as a global condition because of the ways in which in most research to date postsocialism was used as a descriptor (without being redefined) in such a variety of contexts (privatization in Poland, economic reform in China, deregulation in Vietnam, etc). We felt that putting this scholarship into conversation could yield something potentially exciting in terms of commonalities (but not as a comparative project that would just collect data and think about similarities and differences). Rather, we wanted to think about the potential to undermine the seeming inevitability of liberal politics as having a monopoly on ideas of justice in the present by thinking about contradictory political formations that are marked by socialist legacies, yet that, in the present, themselves don't reproduce grand narratives of a singular revolutionary futurity. For instance, in her article for our special issue, Erin McElroy (2018) provocatively begins by recounting a fistfight between nihilists and Marxists in Oakland, California as an entry point for theorizing the "gentrification," dispossession and displacement driven by the so-called Tech Boom 2.0 in the San Francisco Bay area and postsocialism. As McElroy proposes, "these two conditions - that of nihilistic despair and that of being haunted with some semblance of hope for revolutionary futures past - when compounded upon local and global theatres of dispossession, fashion something new" $(2018,4)$. Thus, she contends, postsocialist time enables a consideration of conflicts around the futurity of Silicon Valley and an emphasis on Silicon Valley as a racial and spatial form. McElroy's piece demonstrates that, as an analytic reimagining of political-temporal relations, postsocialism is a methodological and conceptual tool that makes legible the contemporary problem-space of seemingly universalized capitalist and liberal global ethos. At the same time, Xiao Liu's (2018) article in our issue tracks apolitical collectivity as connectivity in her discussion of the Brother Orange incident. The incident refers to the media production of a homosocial "love story" between a New York City gay cosmopolitan tech worker and a poor Chinese worker. As Liu (2018) argues, the media production of the two men's "bond" - enabled by the sale of the tech workers lost phone in China, and the emergence of pictures from the phone's new Chinese owner on the New Yorker's storage cloud - in fact erases the vast differences in the economic and social status of the two, not to mention the conditions of production of tech gadgets like the iPhone that enable the fantasy of infinite connectivity in the present. Such an erasure, Liu (2018) posits, is also a part of the postsocialist condition. In this sense, the politics of postsocialist collectivities need not be "progressive."

\section{Decolonial theory, global coloniality, modernity, and race}

Decolonial theory was formed in response to the colonization of Americas; as such, some decolonial debates address the impossibility of 
applying decolonial theory outside of the context of Americas. How do you envision postsocialism is situated in relation to these discussions? For example, in the "Introduction" to the special issue, the connection between decolonial, postcolonial and postsocialist theories serves as an important line of your inquiry: "Pluralizing postsocialisms as a method opens up a space of conversation between decolonial projects like those in the former USSR and those bearing the legacy of third worldist socialisms, among others, without necessarily using the established terms of "postcolonial theory" as the preferred language of that conversation" (Atanasoski and Vora 2018, 150). If postsocialism is not attached to the specific geography and refers to a global condition, in what way is it possible to talk about the postsocialist decolonial theory? It is also a question about postsocialism and global coloniality. How can postsocialism as a theory contribute to the understandings of global coloniality?

We mentioned briefly in our response about postsocialism and queer temporality that certain imperial histories are not currently a part of either postcolonial or decolonial theories. We were less interested in our issue in discussing the fractures between postcolonial and decolonial theory; nor were we interested in the facile move of signaling a progressive politic by simply adding the modifier "decolonial" in front of certain political movements. As we suggested above, postsocialism(s), conceptually and methodologically, ask that we not treat state socialist histories as aberrant or improperly aligned with the "natural" progression of Euro-American global modernity (along with its economic, social, and racial configurations). Rather, the concept references and centers socialism and asks us to consider the enduring legacies of the histories and lifeworlds of these "illiberal" or noncapitalist formations as never fully erased. As Jon Beller, a contributor to our issue has suggested to us, we can in some ways think of the "post" as being in quotation marks or bracketed.

Along these lines, we can also take seriously the ongoing legacies of other imperial formations, like the Russian or Ottoman Empires, each of which lay beneath the particular form that state socialisms took in Central and Eastern Europe. Madina Tlostlanova (2015) has called these empires "subaltern" or second-rate empires. This is a useful conceptualization in the sense that it accounts for the ways in which the Soviet, Russian, or other non-Western empires (the Japanese or Chinese) are not considered as a part of the making of our global coloniality (though, of course, they are). Yet the argument that "second-rate" empires merely copied the West (this is Tlostlanova's argument about Russia), does not fully account for the specificity of the form of these empires and how this specificity also shaped our modernity. In this sense, it still applies existing postcolonial/decolonial understandings of race and other forms of difference (which have been theorized in relation to other geopolitical contexts and regional histories) and applies them onto post-imperial formations where they may not apply. Might socialism itself and the partic- 
ular forms it took be tied to the differing imperial legacies in different places (for example, in the former Ottoman colonies, or in the formerly Russian colonies)? Relatedly, what about the socialisms that arose in African nations, or liberation theology in Latin America, or pro-indigenous anti-colonial naxalism in India? How were these socialist socialities differently positioned in relation to anti-imperial movements? A postsocialist decolonial theory might thus emphasize relationality even as it connects socialism to anti-imperialism. At the same time, of course, it is important to recognize the imperial relation of the USSR to its peripheries and satellites. But as we do so, it is crucial not to replicate the Cold War discourse around Soviet imperialism that demonized the USSR to imagine the US as a beacon of anti-imperialism and democracy. In this sense, postsocialism as a concept asks us to think about shifting imperial forms during the cold war, how they build on earlier imperial formations and transform them as part of shifting geopolitical configurations of our global modernity.

A recent article by Piro Rexhepi (2018) provides a great example of what this might look like in contemporary scholarship interested in theorizing postsocialist politics. Rexhepi argues that whereas socialism was aligned with anticolonialism, in the period after the demise of state socialism in Bosnia and Herzegovina there has been an attempt to erase the history of the Habsburg empire for the purposes of EU integration. Amnesia about the Habsburg empire is part of a dominant narrative of the European Union as a post-imperial formation. Rexhepi argues that whereas Gavrilo Princip, who assassinated Archduke Ferdinand, was remembered as a hero of liberation under socialism, he has, in line with European history, now been reclassified as a terrorist. As Rexhepi powerfully shows in his piece on the renovations happening in the cityscape of Sarajevo to bring it in line with the timespace of the EU, protesters who objected to this sanitizing of Habsburg past as non-imperial rely on socialist history to do so (emphasizing the worker, the importance of public space, and memories of histories rendered aberrant to Euro temporality, like that of the Ottoman and the socialist pasts). In this case, socialist legacies and ideas about property, worker dignity, etc. are deeply integrated with a decolonial protest against the neo-imperial forgetful temporality of EU integration.

Following the conversation about thinking of the enduring legacies of socialist formations, we have a further question about postsocialism, race and decolonial praxis. In the "Introduction" to the special issue Postsocialist Politics and the Ends of Revolution, you discuss the problems you faced in searching a place to publish the special issue that you relate to the "dominant understanding in the U.S. academy that there was nothing left to say about the ostensible end of socialism and its legacies, not to mention that, with the association of postsocialism with Central and Eastern Europe, it also reaffirmed the impossibility of imagining this region as fertile theoretical ground for advancing conversations 
in race or decolonial praxis" (Atanasoski and Vora 2018, 142). How does postsocialism allow bringing the former state socialist region into the conversation about race, imperialism, and colonialism?

One interesting development since we wrote this introduction is that, following the election of Donald Trump, a number of articles have been published that actually make the case that Eastern Europe can now be useful (theoretically) to the rest of the world because of its history of fascism and totalitarianism. Dace Dzenovska and Larisa Kurtovic (2018) have recently argued that there are several major areas where Eastern Europe can teach the West valuable lessons about the futures it will live out. They name 4 major areas where this occurs: (1) knowledge of totalitarianism/authoritarianism; (2) knowledge of fascism/nationalism; (3) knowledge of Russia; and (4) prefiguration of the future of the West. But even in this formulation, the knowledge that comes out of the East is never one filled with political possibility, but rather political hopelessness. Thus, if Eastern Europe is always totalitarian/fascist, it is always racist (and not a place from which to theorize the resistance of the marginalized). This erases the many interesting routings of black radicals (for instance W.E.B. DuBois) through the USSR (the historian Kate Brown has explored this in her work). But it also fails to account for the ways in which Eastern Europe is a site that has been racialized in multiple imperial histories that are overlapping.

To the point, in the "Introduction" to the special issue Postsocialist Politics and the Ends of Revolution, you mention that liberalism is intertwined with fascist trends, while liberal formations are presented as oppositional to fascist tendencies. Could you explain the complementarity of liberalism and fascism? And how the positioning of liberalism as the antithesis to fascism limits our understanding of political action, protest, and subjectivities?

This question is interesting to think about in relation to our earlier response (where liberalism is posited as the solution to Eastern Europe's ostensible problem of being a condensed articulation of all things associated with fascism/totalitarianism). Yet liberal reforms are themselves violent - and can be a form of terror, as in the case of shock therapy, or the process of privatizing state and worker-owned factories across post-socialist spaces. According to Nikhil Pal Singh, a "liberal" order has long been associated with the values of "universality, open-mindedness, and tolerance," as well as with the utmost primacy on individual freedom as opposed to collectivism (Singh 2014, 153). Two strains of liberalism have traditionally been theorized separately: the first, market liberalism supporting free trade and unregulated markets; and the second, political liberalism centering citizen subjects as juridical subjects rendered equal before the law. Yet, within the context of privatization and socio-economic "transition" that was part of the dismantling of state socialism across Central and Eastern Europe and also, globally speaking, neoliberal 
world-bank driven reforms, the entanglement of the two (the market and the juridical) and, therefore, the need to assess their co-constitutive effects, is obvious. Across Central and Eastern Europe, privatization and the institution of market economies was seen as leading to juridical rights and the rule of law after the demise of state socialism. For instance, the legacies of communism were often blamed for the wars that broke out across the former Yugoslavia. At the same time, As Achille Mbembe explains, it is crucial to remember that "European liberalism was forged in parallel with imperial expansion. It was in relation to the expansion that liberal political thought in Europe confronted such questions as universalism, individual rights, ... international justice, [and] the nature of the relationship between European and extra-European worlds" (Mbembe 2017, 55). Building on Mbembe's argument, we can understand privatization, juridical reform, movements against corruption in the postsocialist world, etc. as the most aspirational Euro-American liberal values. Yet, this is also about the ongoing production of Europeanness or Western-ness through the aberrance of non-European worlds - pointing to illiberalism or those histories not aligned with capitalist modernity as aberrant (illiberal, unjust, criminal). This is a narrative that fails to account for the ways in which liberal principles are in fact founded upon histories of slavery, imperial violence, and economic expropriation.

Your answer brings to mind one more process, i.e. decommunization that has been happening in some former state socialist countries in conjunction with the processes of neoliberalization and "Europeanization." We think that postsocialism as a temporal and decolonial analytic that, as you write in the "Introduction," "creates space to work through ongoing legacies of socialisms in the present" (Atanasoski and Vora 2018,141 ) is necessary in order to reflect on and address the politics of decommunization in Eastern and Central Europe that entails neoliberal changes in the levels of policy-making, discursive shifts, ways of thinking about social organization, collectivity and everyday practices, and reconfigurations of public space. Moreover, such projects of decommunization happened in many former state socialist countries as the processes of homogenizing/universalizing of political imaginary. In this situation, postsocialist queer temporality that we discussed above enables radical modes of responding to the neoliberal logic and opens new conversations about racial capitalism and colonialism, while acknowledging Soviet imperial racial, sexual, gender, and economic hierarchies. In this sense, our next question relates to the ways of countering modernity scripts. What language may be generative to think through and communicate the lifeworlds that would be disruptive of the scripts of modernities (Soviet socialism and Euro-American liberal democracy) and the nation-state paradigm? How can we challenge the forgetting of lifeworlds incommensurable with either of the modernities and vio- 
lence related to them? For example, what do you think of the language and aesthetics of the visual, considering the violence and objectification inscribed in it within the modernity paradigm?

A great example that may be useful for thinking through your question is the "Four Faces of Omarska" project that [Neda] has written about in a recent (2018) article. The project is spearheaded by the Belgrade-born artist Milica Tomic and a large collective of artists, scholars, and survivors of the concentration camp at Omarska that was active during the wars of secession in the former Yugoslavia. Omarska is remembered in the global imagination as one of the most horrific examples of the "barbarism" of the Yugoslav wars of the 1990s and the so-called ethnic-hatreds that resurfaced after communism ostensibly suppressed nationalism that never went away after WWII. Because the camp was an iron ore mine during the socialist era, and because in the postwar epoch it is once again an active mine, there is currently no memorial at the site of the camp.

In response to this problem, the Four Faces of Omarska group conceived a kind of memorial that seeks to create an "active exhibition that [will]... comprise an inter-archive of materials ... such as: documents, interviews, videos, photos, performances, discussions/interventions etc., [and] that will be continually updated and cross-linked" (Tomic ND). By inter-archive, the group means to indicate not just different kinds of texts that are assembled by participants, but also the interactive component - how participants engage and make the texts come to life across different temporalities. This engagement is a form of social sculpture and not a physical sculpture that would more traditionally serve to memorialize the victims of war crimes. "Social sculpture," a term put forward by Joseph Beuys in the 1960s, conceives of art and archiving as inclusive, participatory, multidimensional, and above all, about uncertainty. Social sculpture works with and attempts to sculpt social changes in these ways. As the group puts it, "Four Faces of Omarska is an ongoing art project that questions strategies of memorial production from the position of those whose experience and knowledge have been subjugated, excluded and disqualified, pushed outside public remembrance and public history." 1 The "texts" produced by the working group are dependent on the network of people participating in the production of archival materials tied to Omarska. Their form (or what they will look like) is not known at the outset because it depends on conversations between the participants (artists, activists, survivors).

"The Four Faces of Omarska" dwells in a multiplicity of time and place, entangled as they are in Bosnia's losses since the demise of state socialism. As the collective has explained,

The title Four Faces of Omarska comes from four constitutive layers in the history of this mining complex in northern Bosnia. [Omarska] was established in socialist Yugoslavia as an iron ore mine...; at the beginning of the 1990s wars, Bosnian Serb forces and local authorities transformed the mine into a concentration camp for ethnic Muslims and Croats; after the 
war, in 2004, [the Austrian-based Arcerol Mittal company, the largest steel producer in the world], assumed majority ownership of the Omarska mine and resumed commercial mining operations; finally, in 2007 it was used as a film shooting location for Saint George Slays the Dragon, the historical ethno-blockbuster ([based on the] First World War) co-produced by film companies from Serbia proper and Republika Srpska [in Bosnia] (Open Space "Film Bulletin 'Four Faces of Omarska'” ND).

In the project, then, Omarska evokes several competing notions of the past, present, and future, and of production, value, crime, death, and life. These facets of the "Four Faces of Omarska" encapsulate the tensions between capitalist production and competing notions of time and place and frame postsocialism as a global condition in which such contests take shape. Speaking about her involvement with the project, Milica Tomic has argued that to understand the wars and crimes of the 1990s, as well as the ways in which the wars of the 1990s have been put to use in the name of liberal governance, it is necessary to contend with "the transition from socialism to capitalism, which began during the course of the war and is still ... ongoing. The process of appropriating public property ... in the name of ... transition ([and] the ties connecting global capital and the local ruling structures), [can be understood as] a form of the extreme terror [and] as a means and a medium of robbing the population" (Fluid States ND). Rather than reproduce the dominant narrative of a transition from totalitarianism to democracy, Tomic here deploys the post-9/11 discourse about terrorism, asking what it might mean to conceive of the dissolution of Yugoslav socialist self-management as a mode of terror.

\section{Solidarity and collectivity}

How can postsocialism serve as a methodology of thinking about transnational solidarity, as well as inform or change the understanding of "transnational"? How does postsocialism as a methodology and a global condition allow re-thinking transnational through transnational dynamics of race, nationalism, ethnicity, colonialism, and sexuality?

To answer your question we turn to [Neda's] article "A Feminist Politics and Ethics of Refusal: Teaching Transnational Cinema in the Feminist Studies Classroom" (2016) that offers important insights about transnational perspective. For this reason, further we use excerpts from this article.

In the article, [Neda] starts discussion about transnational analysis in feminist studies with the 2013 statement on women's studies scholarship where the United States-based National Women's Studies Association Field Leadership Working Group Members named transnationalism as one of the "four key concepts central to women's and gender studies scholarship, teaching, and service." The report describes the scope of transnational feminist analysis thus: 
Transnational analysis in women's and gender studies examines power, privilege, and differences within and across boundaries and through processes ranging from the intimate to the global. ... Analyses intervene in hierarchical paradigms and resist binaries of local/global or domestic/ international. Note that the transnational is not conceived as indicating a location "over there" but rather is approached as an analytic that enables practitioners to comprehend the impact of global processes across spaces, over time, in distinct locales, and in the intimacy of homes and bodies. Transnational analysis decenters "the center" wherever it may be, and it explores the way that the center is always multiply constituted in and through its relationship to the periphery (as cited in Atanasoski 2016, 222-223).

This definition envisages a transnational feminist analytic that is mobile, intervening in established binaries and spatial and temporal hierarchies, thus destabilizing entrenched nationalist and hegemonic knowledge formations. The NWSA's characterization of transnationalism is politically and pedagogically useful in many respects. Nonetheless, the problem of being everywhere and nowhere all at once that Rachel Lee pointed to with regard to the category "women of color" remains applicable to this contemporary demarcation of the transnational. As Lee writes, "the seduction of nonterritoriality ... is also a seduction for women's studies scholars more generally" (as cited in Atanasoski 2016, 223). In turn, through their educational paths in the field of feminist studies, students are themselves seduced by the nonterritoriality of the transnational. A number of feminist scholars have raised similar concerns about interdisciplinary institutional formations that uncritically celebrate border crossing at the expense of groundedness in area studies. Along these lines, Leela Fernandes (as cited in Atanasoski 2016, 223) has argued that precisely because transnational feminist analytics and approaches have attempted to "delineate new spaces" not tied to "the territoriality of the nation-state," territorial formations like the nation state can now only be addressed through an implicit contrast with the celebrated space of border-crossing. Ensuing "regimes of visibility," Fernandes contends, discipline the feminist imaginary, even if differently, than older nation-based paradigms.

Fernandes's notion of transnational "regimes of visibility," and the possibilities and limits of such regimes to transform feminist studies students' engagement with the world, is particularly provocative in relation to postsocialism as a complementary but also at times contradictory theoretical frame to that of the transnational. For instance, following the end of the Cold War, the former second world fell out of visibility within predominant U.S. (inter)disciplinary and transnational paradigms. As the Global North and Global South conceptually displaced the old three worlds model, scholarly work either subsumed formerly state socialist nations into the Global South, or, for the nations seen as successfully participating in capitalist development, into an undifferentiated Europe (the Global North). While such tendencies to erase the former second world from relevant cultural and political knowledge has 
been rigorously interrogated by scholarship explicitly invested in theorizing postsocialism as a global condition, to date, most transnational feminist and cultural analyses have marginalized postsocialism as a regionally specific analytic that is relevant only for Central and Eastern Europe. In short, the historical and cultural legacies of state socialism are unaccounted for in U.S. based feminist conceptions of the transnational.

According to Jennifer Suchland (as cited in Atanasoski 2016, 224), for instance, in spite of transnational feminism's stated commitment to "destabilizing fixed geographies and seeing the intersections and hybridity of power," it has privileged and indeed conflated the "third world" with the "transnational." She reasons that the second world's status as "nonregion" is due to the fact that its mode of "difference" is not recognizable as a difference that matters in women's studies scholarship. This is in part because of the racialized understanding of the "global" within a U.S. academic context, and in part because during the Cold War the second world was not viewed as critical of the first world, but, rather, as wanting to join it through processes of democratization and Europeanization.

At the same time, as Katarzyna Marciniak (as cited in Atanasoski 2016, 224-225) has compellingly argued, any project invested in theorizing how the former second world might unsettle existing transnational feminist epistemologies should not stop short at adding categories "to the list of 'other worlds' so that it [can] compete with them for attention." Instead, she contends, it may be more useful to contemplate the "discursive disappearance" of the post-communist world a place from which to rethink how and why the Western gaze is directed and diverted differentially in relation to geopolitically and historically specific "threats." Put otherwise, rather than figuring the terms through which Central and Eastern Europe might be brought into the transnational paradigm, the more challenging, and therefore, perhaps, also the more productive problematic is that of how seemingly politically progressive paradigms (like transnational feminism) themselves participate in disappearing not just certain parts of the world, but also ways of life, from the realm of relevant knowledge. We could ask what might it mean to think through the materiality of postsocialist disappearances beyond the regional frame? [Excerpted from (Atanasoski 2016)].

We also think that it is important to discuss solidarity and collectivity in terms of ethics. For example, in the "Introduction" to the special issue Postsocialist Politics and the Ends of Revolution, you refer to the "new ethical collectivities" (Atanasoski and Vora 2018, 141) that oppose military, economic, and cultural expansionism. It is interesting that you use the term "ethical collectivities." What meanings do you include in the terms "ethical" and "collectives"? Could you give examples of new ethical collectives? What moments of solidarity do you think could open other possibilities to imagine postsocialist queer feminist communities locally, transnationally, and globally? 
[Kalindi's] recent article "Biopolitics of Trust in the Technosphere: A Look at Surrogacy, Labor, and Family" (2018) offers great ideas and examples for the question. Therefore, in order to answer it, we use excerpts from this article that provide important insights for thinking about ethical collectives.

When [Kalindi] started researching transnational Indian surrogacy arrangements in 2008, she spent several months at a surrogacy clinic in north India. [Kalindi] found an insistence among surrogates that common sense should dictate it should be commonsensical that commissioning parents would naturally feel that they owed their surrogate an extended form of patronage, in light of what the surrogate had given them - something beyond what money can repay or represent. In fact, such relationships between people of power and resources and those of little have well-established precedents in South Asian history (Vora 2013). The social contract that binds the nation together, where citizens subject themselves to state power in exchange for security, is a model for the marriage contract. It is also a model for surrogacy contracts. The social contract (and its reproduction in the labor and marriage contracts) - an agreement between two supposedly autonomous parties that will be upheld by the state legal apparatus - makes one party, in this case, the surrogate, subordinate to another, here the commissioning parents, because by law she is a temporary service worker who will gestate their property and progeny for 9 months after which she is no longer part of the parent's, or the commissioned infant's, social world.

The modern nuclear family as an ideal is a relatively recent invention consisting of a set of people living together in one household economic unit recognized through tax reporting, medical insurance registration, school enrollment, death benefits, visitation and custody rights, etc. In the United State, it wasn't until the early- to mid-20th century that the heteropatriarchal nuclear family became the privileged site of the citizen subject. In his book Contagious Divides, Nayan Shah explains how in the US in the mid-20th century, anxieties about immigration and racial intermixing were part of a national project to promote the members of the white, middle-class nuclear heteropatriarchal household as the ideal citizen subject. He explains that many alternate domestic formations existed at the time, and that these were pathologized to support the ideal family household. In reality, of course, most households do not match this imaginary of the nuclear family - in fact, we can see these "queer domesticities" as Shah calls them, as protesting the reproduction of the nation because they destabilize the white nuclear family norm. Shah described those intimacies and domesticities that are non-productive in a capitalist frame, and that don't replicate the idealized citizen-subject out of that white middle-class nuclear family. Mixed families, single mothers raising children unofficially with cooperative arrangements with other single mothers, grandparents housing and supporting adult children and grandchildren... the list goes on. 
What types of communities of care might arise, then, out of the retraction of the social welfare state? Can we see these as both a symptom of the failure of the state, but also as sites of possibility to interrupt the easy reproduction of the nation and the family form? The way former surrogates in India describe the potential for structures of life-long responsibility between commissioning parents and the families of surrogates helps us imagine alternatives to nation-state organized family and marriage-based structures of kinship and mutual aid.

"Who can trust me to care for them" is a question of building collectives within or despite the nation. Collectives have historically challenged the model of the autonomous individual property owner. Surrogates who feel they should be in a relation of responsibility with commissioning parents are calling for those parents to think about a collective investment. Whom will they care for? The genetic progeny borne by a surrogate because it is a relation sanctioned by the state, but not the surrogate? Many people are already living as part of alternative collectives - those queer domesticities that the nation has tried to sanction. [Kalindi] has argued that in some ways, social reproduction and the domestic sphere have always been such a place even as they have been central to racial, gender and imperial exploitation [excerpted from (Vora 2018)].

Your answers make us think of one more dimension related to the question of solidarity. One of your approaches to postsocialism is through queering the temporality and building on the past conditional temporality "what could have been" suggested by Lisa Lowe (2015). This is one of the ways to disrupt liberalism, its politics of forgetting, and the present-day neoliberal policies. Consequently, you state that it is important to explore how "the grounds for political solidarity and coalition have been formulated" in order to prioritize "obscured historical connection between past and present" (Atanasoski and Vora 2018, 143). Therefore, pluralizing postsocialisms and challenging liberal forgetting bring into light transnational movements (such as black internationalism and third-worldism), political actions and ethical collectivities and the connections between their past and present examples (Atanasoski and Vora 2018, 141). Could you name examples of collectives invested in excavating the past and present politics?

Your question brings to mind the terrific documentary work of Canadian-Yugoslav filmmaker and researcher Tamara Vukov called Tranzivija/Transition (forthcoming 2019). In it, Vukov documents in two parts the multi-year struggles of factory workers in Serbia in the 2000s to maintain their ownership stakes in the factories in which they had worked. "Transition" or privatization occurred later in Serbia than in the rest of Central and Eastern Europe because of the Milosevic regime than had remained in power throughout the 1990s. 
The first part of Vukov's documentary project, Tranzicija/Transition: Zrenjanin focuses on the three-year strike organized by the mostly women workers of the Zrenjanin Jugoremedia pharmaceutical factory. The second part, Tranzicija/Transition: Yugo turns its attention to the decimated auto and steel industries in the Zastava plant in Kragujevac. Both films tell a history of socialist self-management and shed light on the human costs of global capitalisms' need to erase socialist modes of sociality in the course of privatization. In contrast to commonplace association between capitalism and the growth of industry and wealth that has often been contrasted with austerity, scarcity, and poverty under socialism in the Western Cold War and post-Cold War imagination of the East, Vukov's two documentary films demonstrate the extent to which privatization decimated industrial infrastructures in the former Yugoslavia, leading to extreme poverty and hardship for families.

The documentaries showcase people's refusal to accept what has in dominant global media and political discourses been characterized as the inevitable political outcome of the end of state socialism - that is, privatization and a liberal individualist politics that dominate the postsocialist landscape. Instead, Vukov's documentary project sheds light on the persistence of an ethos of collectivity and justice instilled in the unique system of self-management that was part of ex-Yugoslavia's state socialist formation. To be clear - this is not a project that falls into the pitfalls of nostalgia for state socialism. Rather it tells the unique story of worker self-management in Yugoslavia that remains untold (Yugoslavia was a unique case and was not a part of the so-called Eastern Bloc). In this sense, Vukov's Tranzicija Files make an invaluable contribution, because they do just that - explore the ethos of self-management and its articulation in the moment of its attempted erasure.

Part of what we are saying here is that the work of provincializing Soviet state socialisms also allows us to draw attention to the ways in which the particularities of state socialism allow for an ongoing if different mode of collective protest in the present (in this case, socialist self-management).

Postsocialisms may reveal multiple understandings of "common," which is, actually, one of the questions in your new forthcoming book Surrogate Humanity: Race, Robots, and the Politics of Technological Futures. Could you talk more about the multiple understandings of "common" and also why is it necessary to raise a question of how we consider "common" in the contemporary conditions of capitalism?

In one chapter of our book, we consider how concepts (including collaboration, sharing, and the commons) have undergone a radical decontextualization as they have risen to prominence as descriptors of what makes the technological innovations of the fourth industrial revolution socially and economically revolutionary. In the book, we argue that the tech economy appropriates collaboration, sharing, and the commons to announce capital's unprecedented liberatory potential, while divesting the concepts it uses from 
an anticapitalist politics and ethos. In 2015, the Oxford English Dictionary introduced "sharing economy" as a term it would now include. The sharing economy is a socioeconomic system built around the sharing of human, physical, and intellectual resources, especially those that individuals may see themselves as possessing and underutilizing (Airbnb, where people rent out unused rooms to travelers, is one well-known example). The sharing economy thus includes collaborative creation, production, distribution, trade, and consumption of goods and services by different people and organizations. The sharing economy is framed as being built on "distributed power and trust within communities [of users] as opposed to centralized institutions," blurring the lines between producer and consumer. Based on the name alone, the much-touted sharing economy, enabled by digital connectivity and wide distribution of the means of production, sounds like it approaches a socialist ideal of "the commons," land or shared resources belonging to a whole community that provide life necessities. Yet, although the sharing economy is sometimes also referred to also as the "collaborative economy" because of initiatives based on horizontal networks and the participation of a community, "community" is defined tautologically as simply the whole of those who participate as users.

Our book critiques imaginaries of the so-called "creative disruptions" to capitalism, which propose that technology will bring about the end of capitalism as we know it through the creation of a collaborative commons built on the internetworking of things and people in the sharing economy. We contend that unlike Marxist feminists, who have theorized the rise of capitalist wealth accumulation as dependent on the unpaid labor of racialized and gendered populations, technoliberal appropriation of collaboration, sharing, and the commons reproduces the erasure of racialized and gendered work in their postcapitalist techno-utopias. Within what we call technoliberalism in our book, the commons, once the staging ground and goal of potential socialist proletarian revolution, is evacuated of political content. Sharing becomes an anonymized market transaction that can sidestep the social and what Marx called "species life," a material and ontological underpinning to the commons that gave it a teleologically revolutionary potential. Put otherwise, our critique of the "sharing" in the sharing economy, as our critique of the "collaborative" in collaborative robotics, draws attention to the ways in which the architecture of postindustrial surrogate humanity works through the elision of the racial and gendered dimensions of capitalist development in its production of the fully human. We investigate the ways in which socialist concepts of collaboration, sharing, and the commons have been appropriated within technoliberalism for purposes of accumulation and expropriation, even as technoliberalism claims freedom and equality as its express end goal. In contradistinction to the recently popularized discourses of the sharing economy, and to a lesser extent collaborative robotics, imaginaries of technology, sharing, and collaboration from Marx and Engels' Communist Manifesto 
to Haraway's A Cyborg Manifesto offer their political motivations as being at the heart of their uses of technology as "decolonizing" and "liberating." At the same time, as feminists and critical race thinkers have pointed out, even these imaginaries risk refusing difference in the name of a universal (humanist) revolutionary call [excerpted from (Atanasoski 2016)].

Atanasoski, Neda. 2013. Humanitarian Violence: The U.S. Deployment of Diversity. Minneapolis and London: University of Minnesota Press.

Atanasoski, Neda. 2016. "A Feminist Politics and Ethics of Refusal: Teaching Transnational Cinema in the Feminist Studies Classroom." In Teaching Transnational Cinema Politics and Pedagogy, edited by Katarzina Marciniak and Bruce Bennett's, 219-235. New York: Routledge

Atanasoski, Neda. 2018. “'Seeing justice to be done': the documentaries of the ICTY and the visual politics of European value(s)." Transnational Cinemas, 9 (1): $67-$ 84. DOI: $10.1080 / 20403526.2018 .1471795$

Atanasoski, Neda, and Kalindi Vora. 2018. "Introduction: Postsocialist Politics and the Ends of Revolution." Social Identities 24 (2): 139-154. DOI: 10.1080/13504630.2017.1321712

Atanasoski, Neda and Kalindi Vora. 2019 (forthcoming). Surrogate Humanity: Race, Robots, and the Politics of Technological Futures. Durham: Duke University Press.

Douzinas, Costas. 2007. Human Rights and Empire: The Political Philosophy of Cosmopolitanism. New York: Routledge-Cavendish.

Dzenovska, Dace and Larisa Kurtović. 2018. "Introduction: Lessons for Liberalism from the Illiberal East.” Hot Spots, Cultural Anthropology (online series), April 25: https://culanth.org/fieldsights/1422-lessons-for-liberalism-from-the-illiberal-east

Fluid States. ND. "Four Faces of Omarska." http://www.fluidstates.org/page. php?id=39.

Hartman, Saidiya V. 1997. Scenes of Subjection: Terror, Slavery, and Self-Making in Nineteenth-Century America. Oxford: Oxford University Press.

Liu, Xiao. 2018. "The travel of an iPhone: Ineluctable connectivity, networked precarity, and postsocialist politics." Social Identities 24 (2): 255-270. DOI: 10.1080/13504630.2017.1321720

Lowe, Lisa. 2015. The Intimacies of Four Continents. Durham and London: Duke University Press.

Manokha, Ivan. 2009. "Foucault's Concept of Power and the Global Discourse of Human Rights." Global Society 23(4): 429-452. DOI: 10.1080/13600820903198792

Mbembe, Achille. 2017. Critique of Black Reason. Translated by Laurent Dubois. Durham: Duke University Press.

McElroy, Erin. 2018. "Postsocialism and the Tech Boom 2.0: Techno-utopics of racial/spatial dispossession." Social Identities 24 (2): 206-221. DOI: 10.1080/13504630.2017.1321718

Pryor, Jaclyn I. 2017. Time Slips. Queer Temporalities, Contemporary Performance, and the Hole of History. Evanston, Illinois: Northwestern University Press.

Quijano, Anibal. 2000. "Coloniality of Power, Eurocentrism, and Latin America." Nepantla: Views from South 1(3): 533-580.

Rexhepi, Piro. 2018. "The Politics of Postcolonial Erasure in Sarajevo." Interventions, DOI: 10.1080/1369801X.2018.1487320 
Santos, Boaventura de Sousa. 2014. Epistemologies of the South: Justice Against Epistemicide. London and New York: Routledge.

Da Silva, Denise Ferreira. 2014. "Toward a Black Feminist Poetics." The Black Scholar: Journal of Black Studies and Research 44 (2): 81-97.

Open Space. ND. "Film Bulletin 'Four Faces of Omarska." http://www.openspace-zkp.org/2013/en/artslab.php?a=3\&w=14.

Shah, Nayan. 2001. Contagious Divides: Epidemics and Race in San Francisco's Chinatown. Berkeley: University of California Press.

Singh, Nikhil Pal. 2014. "Liberalism." In Keywords for American Cultural Studies, edited by Bruce Burgett and Glenn Handler, 139-144. New York: New York University Press.

Tlostanova, Madina. 2015. "Can the Post-Soviet Think? On Coloniality of Knowledge, External Imperial and Double Colonial Difference." Intersections: East European Journal of Society and Politics, 1 (2): 38-58. DOI: 10.17356/ieejsp.v1i2.38

Tomic, Milica. ND. "New Projects." http://milicatomic.wordpress.com/new-projects-2/.

Trinh, Minh-ha. 2016. Lovecidal: Walking with the Disappeared. New York: Fordham University Press.

Vora, Kalindi. 2013. "Potential, Risk and Return in Transnational Indian Gestational Surrogacy." Current Anthropology, 54 (Supplement 7): 97-106. DOI: $10.1086 / 671018$

Vora, Kalindi. 2018. "Biopolitics of Trust in the Technosphere: A Look at Surrogacy, Labor, and Family," Technospheres, August 19: https://technosphere-magazine.hkw.de/p/Biopolitics-of-Trust-in-the-Technosphere-A-Look-at-Surrogacy-Labor-and-Family-nx8Dq5RnoXnQCNcGJ6w3cx

Wynter, Sylvia. 2003. "Unsettling the coloniality of being/ power/ truth/ freedom: Towards the Human, after Man, its overrepresentation - an argument." The New Centennial Review 3(3): 257-337. 